\title{
WIST, Rat Strain
}

National Cancer Institute

\section{Source}

National Cancer Institute. WIST, Rat Strain. NCI Thesaurus. Code C76190.

An outbred strain of albino brown rat, this strain was developed at the Wistar Institute by Donaldson, Greenman, and King (1906) and was the first rat strain in use in biomedical research. The Wistar rat has a wide head, long ears, and its tail length is always less than its body length. A wide variety of rat inbred strains have been derived from the Wistar. 